\title{
Synthesis of micro-particles using Hydrocotyle Ranunculoides (Floating Water Pennywort) and their use in Cadmium adsorption.
}

\author{
Nichodimus Hokonya ${ }^{1}$, Courtie Mahamadi ${ }^{2}$ \\ I'Department of Chemistry, Bindura University of Science Education, Private Bag 1020 Bindura, Zimbabwe, \\ ${ }^{2}$ (Research and Postgraduate Centre, Bindura University of Science Education, Private Bag 1020 Bindura, \\ Zimbabwe,
}

\begin{abstract}
Microparticles were prepared using Hydrocotyle ranunculoides (Floating Water Pennywort) and subsequently used as adsorbent for Cd(II) from aqueous solution in batch systems. The optimum conditions for $C d$ (II) adsorption were investigated by varying the parameters: initial Cd (II) concentration, $p H$ value, contact time, and adsorbent dose. It was shown that the optimum parameters for $\mathrm{Cd}(\mathrm{II})$ adsorption were $\mathrm{pH}$ 5.0, dosage $2 \mathrm{~g} / \mathrm{L}$, initial Cd (II) concentration $50 \mathrm{mg} / \mathrm{L}$ and contact time 240 minutes. The results showed a Langmuir maximum adsorption value of $20.41 \mathrm{mg} / \mathrm{g}$ and a separation factor between 0.72 and 0.91 , suggesting a feasible adsorption process. An E value of $5.59 \mathrm{~kJ} / \mathrm{mol}$ which was obtained using the Dubinin Radushkevich model indicated that the adsorption process was physical in nature. The structure of micro-particles was characterized using scanning electron microscopy (SEM), transmission electron microscopy (TEM), Fourier-transform infrared spectroscopy (FT-IR), Thermo Gravimetric Analysis (TGA), and Energy-Dispersive X-ray spectroscopy $(E D X)$. The EDX profile shows that most inorganic impurities present were totally removed during the steam explosion process. The functional groups present in micro-particles, which have the potential to take part in adsorption are hydroxyl groups as confirmed by the FT-IR spectra. The study showed that the material is a good adsorbent.
\end{abstract}

Keywords: Batch adsorption, Cadmium adsorption, Dubinin-Radushkevich, Hydrocotyle ranunculoides, physical adsorption

\section{Introduction}

Cadmium is used in steel industries, plastics, and batteries manufacture. Diffuse pollution by cadmium is caused by contamination from fertilizers as well as local air pollution and it is released to the environment in wastewater. Impurities in solders, metal fittings, and galvanised pipes can also contribute to cadmium contamination in drinking water. The WHO guideline for Cadmium in drinking water is $0.003 \mathrm{mg} / \mathrm{L}$. The main target organ for Cadmium toxicity is the kidney and it is said to be carcinogenic in large doses[1]. Cadmium is one of the heavy metals polluting Zimbabwean waters[2][3][4].

Conventional methods which are used to remove metals from waste waters have several limitations including high sludge production, handling and disposal problems, technical constraints and high costs[5]. In the past few decades, biosorption has emerged as a potential method for metal removal from aqueous solutions. Dissolved metals from very dilute solutions can be sequestered with high efficiency during the biosorption process thus making the process an ideal candidate for treatment of high volume of low concentration wastewaters[6] ). The advantages of biosorption over conventional treatment methods include high efficiency, low cost, regeneration of biosorbent, possibility of metal recovery, minimization of biological and or chemical sludge[7][8] ).

Agricultural waste which have been successfully used for Cadmium biosorption include unmodified wetland biowaste shoots of Cyperus laevigatus [9], volatization of olive stones and sugar begasse byproducts[10], chemically modified apple pumice[11], Alhaji maurorum seed [12], untreated Pinus halepensis sawdust [13], Strychnos potatorum seed proteins[14], untreated coffee grounds[15]. Recently, attention has also been focused on aquatic macrophytes such as Eichhornia crassipes which, due to their extremely rapid proliferation and congest growth, present serious challenges in navigation, irrigation, and power generation[16]. In our earlier research article, we reported for the first time, competitive adsorptive removal of $\mathrm{Pb}, \mathrm{Cu}$ and $\mathrm{Cd}$ from water using $H$. ranunculoides fixed on alginate. H. ranunculoides has become pervasive in Lake Chivero, Zimbabwe, and is increasingly replacing E. Crassipes [17][18]. The current work investigates the potential of micro-particles prepared using H. ranunculoides as adsorbent for $\mathrm{Cd}$ (II) from aquatic systems. 


\subsection{Materials}

\section{Experimental}

Potassium hydroxide, sodium chlorite, oxalic acid, acetic acid, potassium dichromate, sulphuric acid, ferrous ammonium sulphate, orthophenanthroline, potassium permanganate, hydrochloric acid used was analytical grade and was purchased from Associated Chemicals Enterprises (ACE), South Africa. The 1000 $\mathrm{mg} / \mathrm{L}$ Cadmium standard was purchased from Anacon cc (SA).

\subsection{Equipment}

The following equipment was used during the experiments; Genesis 10s UV-Vis Spectrophotometer (Thermo Fisher scientific (USA), pH meter from Adwa AD1020- Romania, Magnetic stirrer from Stuart Scientific (UK), Analytical Balance from Adam Equipment, Sonicator (Jablo, Germany), FT-IR Spectrophotometer (Thermo Fisher Scientific, USA), Hot Plate (Lasany), Scanning Electron Microscope (Tescan Vega TS 5136LM), TEM (Zeiss Libra 120 TEM), Centrifuge (Astell, London), grinder (Culatto), Orbital Shaker (Griffin-Germany), Autoclave (All American Pressure steam sterilizer) and TGA (Perkin Elmer Delta series).

\subsection{Preparation of H.ranunculoides microparticles}

Microparticles were isolated by steam explosion from the $H$. ranunculoides by the a method described by Deepa et al.,(2011) [19] to eliminate lignin, pectin and hemicellulose. Fig 1 summarises some of the steps involved in the production process of micro-particles.
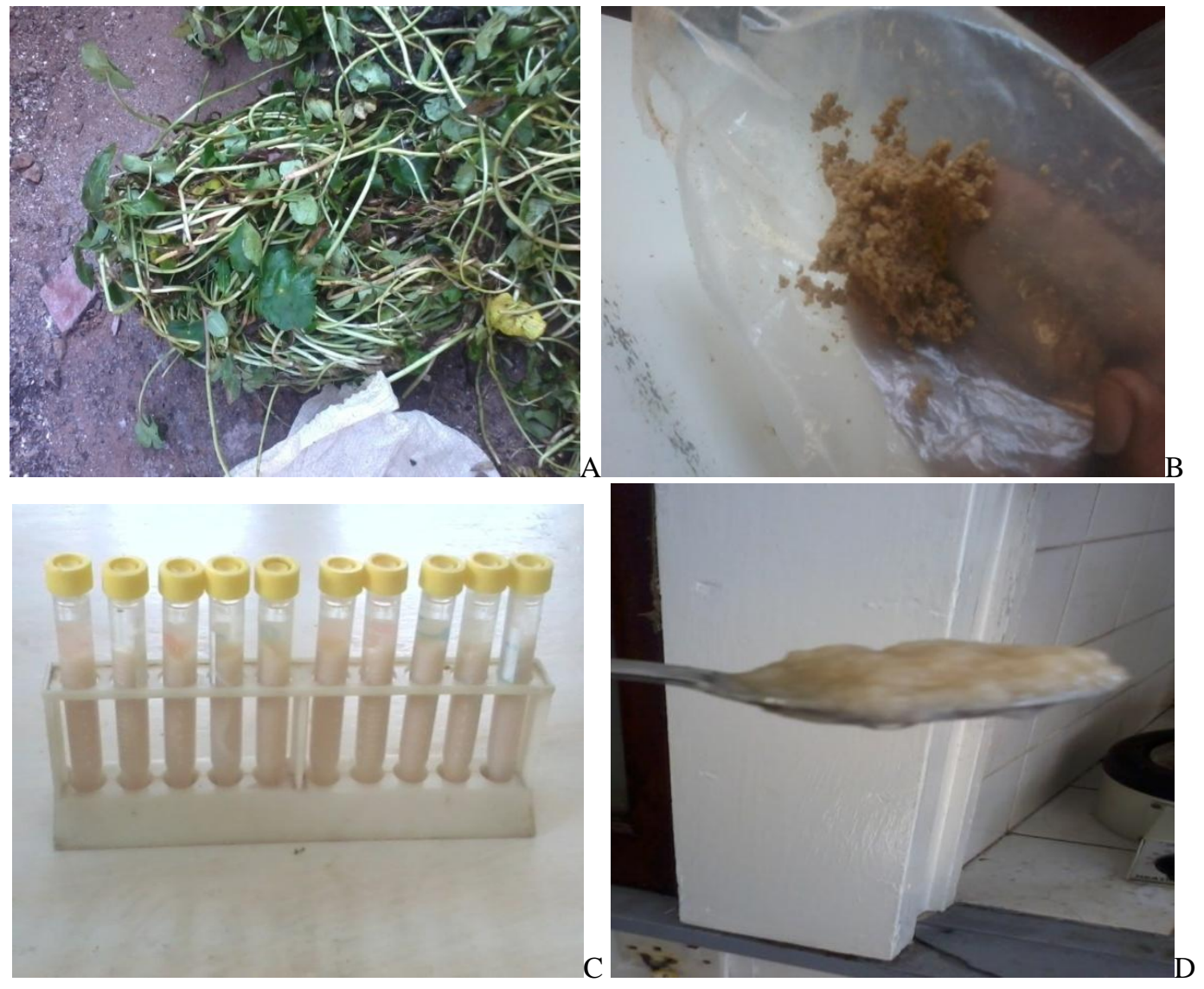

Figure 1. Photographs of some of the steps (A) raw sample (B) alkali treated (C) after centrifugation (D) after acid hydrolysis.

\subsection{Characterisation of the Microparticles}

The functional groups of the chemically treated particles from $\mathrm{H}$. ranunculoides were dertemined by a FT-IR Spectrophotometer by scanning in the range $4000-400 \mathrm{~cm}^{-1}$ and transmission mode at a resolution of $4 \mathrm{~cm}^{-1}$ with 40 scans per each sample. The morphology of the microparticles was investigated by SEM analysis at a minimum $200 \mathrm{~V}$ and maximum voltage $30 \mathrm{kV}$. The micro-particles diameter and length was determined at high resolution. The specimen was deposited on electron microscope grids operated at an 
Synthesis of micro-particles using Hydrocotyle Ranunculoides (Floating Water Pennywort) and ..

accelerated voltage of $10 \mathrm{kV}$ with Scanning mode and observed. The size of the micro-particles was determined by mounting a drop of diluted micro-particles suspension on a carbon coated grid and placed in Transmission Electron Microscopy (TEM), with a resolution of $2.4 \AA$, operating at $20-200 \mathrm{kV}$ and the TEM images were captured. TGA was used to study the thermal properties of the raw material and the micro-particles at a temperature range of $30-950^{\circ} \mathrm{C}$ in a nitrogen atmosphere at a heating rate of $10^{\circ} \mathrm{C} / \mathrm{min}$. Alumel, Perkalloy, and iron were used for temperature calibration.

\subsection{Optimization of adsorption conditions}

The equilibrium adsorption experiments were carried out by a method adapted from (Stephen et al., 2011) [18]. The experiments were carried out by varying dosage from 20-100 $\mathrm{mg}$ of the micro-particles with 20 $\mathrm{mL}$ of initial Cd (II) concentration from $0-80 \mathrm{mg} / \mathrm{L}$ solution in $100 \mathrm{~mL}$ polyethylene bottles in an orbital shaker with constant agitation at $125 \mathrm{rpm}$ between $20-300$ minutes at $\mathrm{pH}$ 2.0-8.0. The mixture was then filtered using a $0.45 \mu \mathrm{m}$ microfilter. The residual metal concentration was quantified using an Atomic Absorption Spectrophotometer at $228 \mathrm{~nm}$.

The adsorption capacity was calculated using $q_{e}=\frac{\left(C_{0}-C_{\theta}\right) V}{m}$

$\%$ Metal removal $=\frac{C_{0}-C_{e}}{C_{0}} \times 100$

Where $q_{\theta}=$ adsorption capacity in $\mathrm{mg} / \mathrm{g}, \mathrm{c}_{\sigma}$ and $\mathrm{c}_{\boldsymbol{\theta}}$ are initial and equilibrium Cd (II) concentration (mg/L), $\mathrm{V}=$ volume of $\mathrm{Cd}(\mathrm{II})$, in $\mathrm{mL}$ and $\mathrm{m}=$ mass of adsorbent used in $\mathrm{mg}$.

\section{Results And Discussion}

\subsection{Characterisation}

\subsubsection{FT-IR Analysis}

The FT-IR spectrum of raw and micro-particles of $H$. ranunculoides is shown in Fig 2 and it suggests the presence of an $\mathrm{O}-\mathrm{H}$ broad band between $3500-3000 \mathrm{~cm}^{-1}$ in both samples, a C-H stretching vibration between $2900-2800 \mathrm{~cm}^{-1}$ appears in both cellulose and hemicelluloses and its more intense in the spectra of H. ranunculoides micro-particles sample. A small peak was observed at $1700 \mathrm{~cm}^{-1}$ in the raw sample only and it was also observed by Krishnan and Ramesh, (2013)[20], Tibolla et al,(2014b) [21] as well as Sundari and Ramesh, (2012)[22] and they attributed to vibration of uronic acid ester linkages of carboxylic groups and the acetyl groups of p-coumeric acid as well as ferulic acid of hemicelluloses and / or lignin. The sharp peak at $1629 \mathrm{~cm}^{-1}$ in micro-particles was probably due to adsorbed water and a similar trend was observed by George, and Narayanankutty, (2016) [23]. The observed peak at $1055 \mathrm{~cm}^{-1}$ is due to the ether linkage of hemicelluloses and lignin another one at $816 \mathrm{~cm}^{-1}$ is due to the $\mathrm{C}-\mathrm{O}$ stretching vibration of cellulose structure, a similar trend was observed by Khawas and Deka, (2015) [25]. The presence of few functional groups (i.e. hydroxyl) in the compound that are able to participate in adsorption suggests a more physical sorption mechanism than chemical.

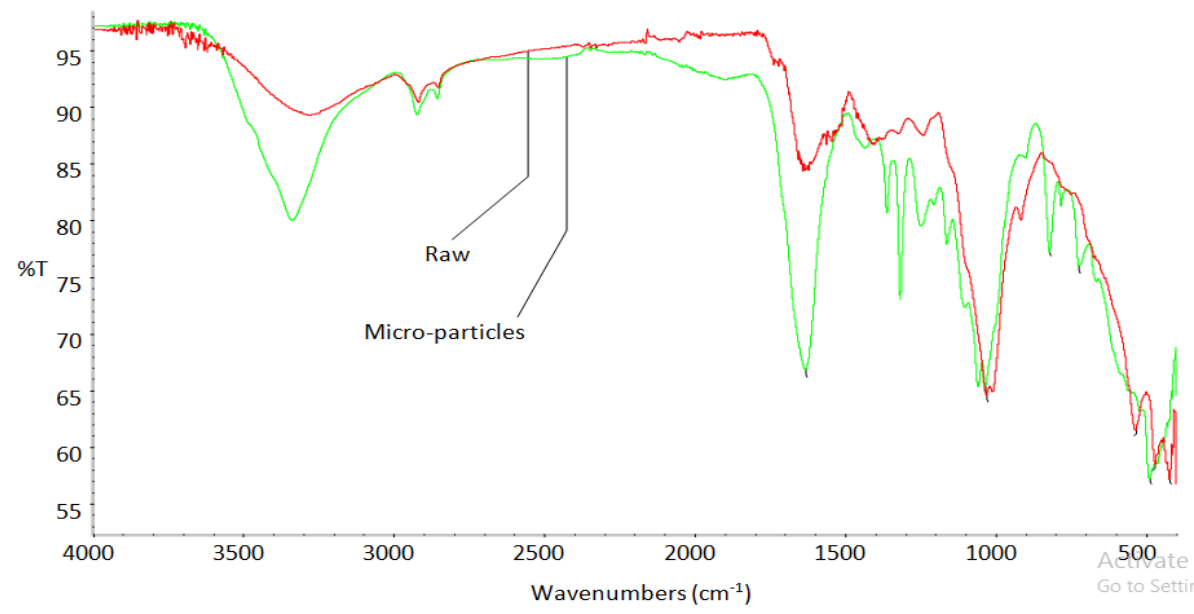

Figure 2. FT-IR Spectrum of $H$. ranunculoides micro-particles 
Synthesis of micro-particles using Hydrocotyle Ranunculoides (Floating Water Pennywort) and ..

\subsubsection{SEM and TEM analysis}

The $H$. ranunculoides micro-particles were analysed by SEM to determine the surface morphology at micron and submicron levels and the SEM micrographs results in Fig 3 shows that the length of the particles was reduced during the treatment process. The pores were exposed and more visible in the micro-particles than in the raw samples thereby suggesting an increase in surface areas. Xiao et al (2015)[26] also found similar results after acid and mechanical treatment. The TEM image shows that the particles are composed of bunches of microfibers that are disintegrated at some points due to the effects of the acid treatment.

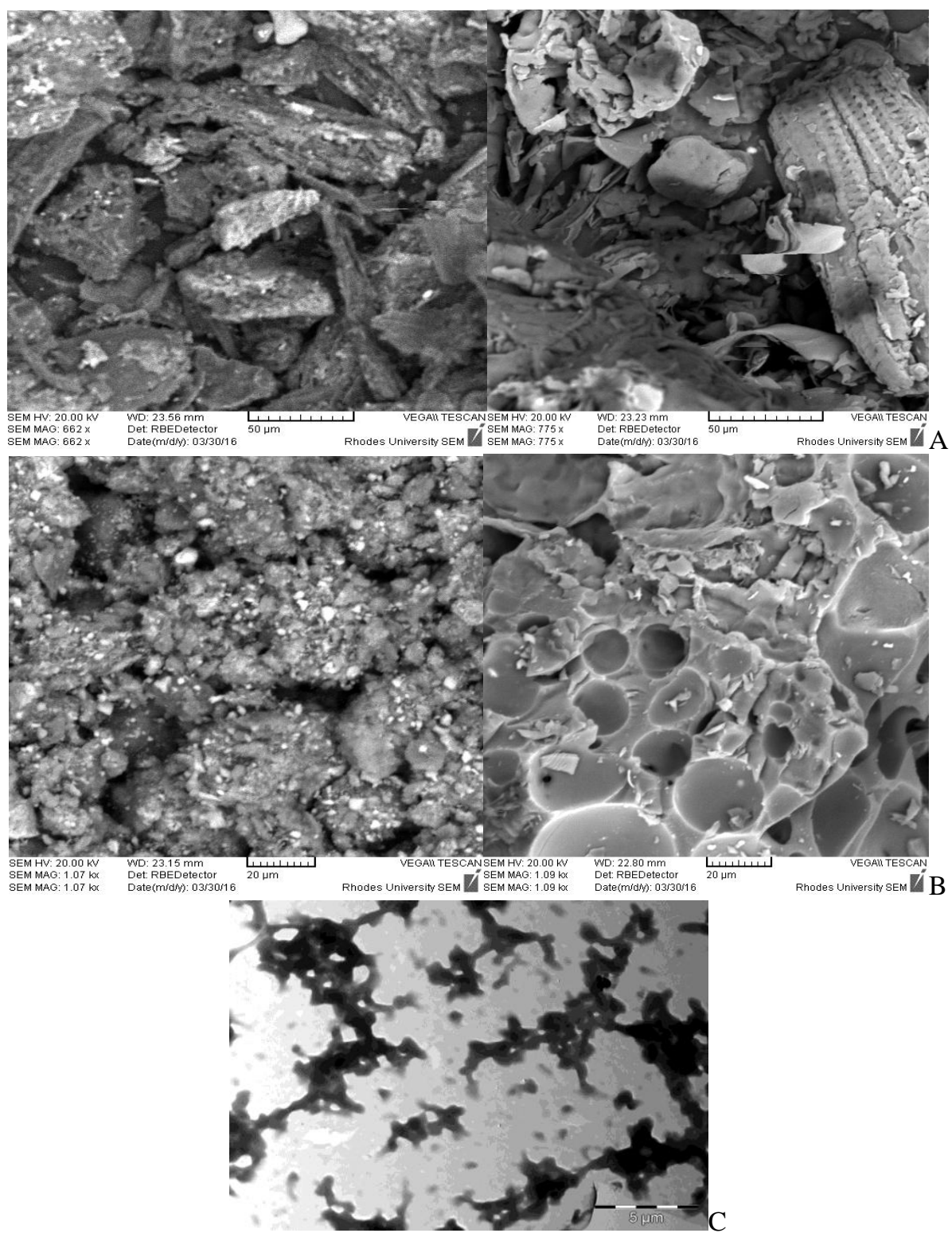

Figure 3. SEM image of the raw sample labelled (A) and micro-particle labelled (B) sample, (C) is the TEM image of the micro-particles.

3.1.3 Energy Dispersive X-ray micro analysis (EDX) Comparison of EDX spectrums in Fig 4 shows that Na, $\mathrm{F}, \mathrm{Mg}, \mathrm{Al}, \mathrm{P}, \mathrm{S}, \mathrm{K}, \mathrm{Mn}$, and $\mathrm{Cu}$ were totally removed during the steam explosion process whereas the amount of $\mathrm{O}$ and $\mathrm{C}$ were reduced however the amount of $\mathrm{Si}$ and $\mathrm{Fe}$ increased. Similar results were obtained by various authors studies by Krishnan and Ramesh, (2013), Xiao et al.,2015'" and 'Kalita et al., (2015) [20] [26][27]. Most of the elements were removed leaving more active sites are free to participate during the adsorption processes in the case of the treated sample. 

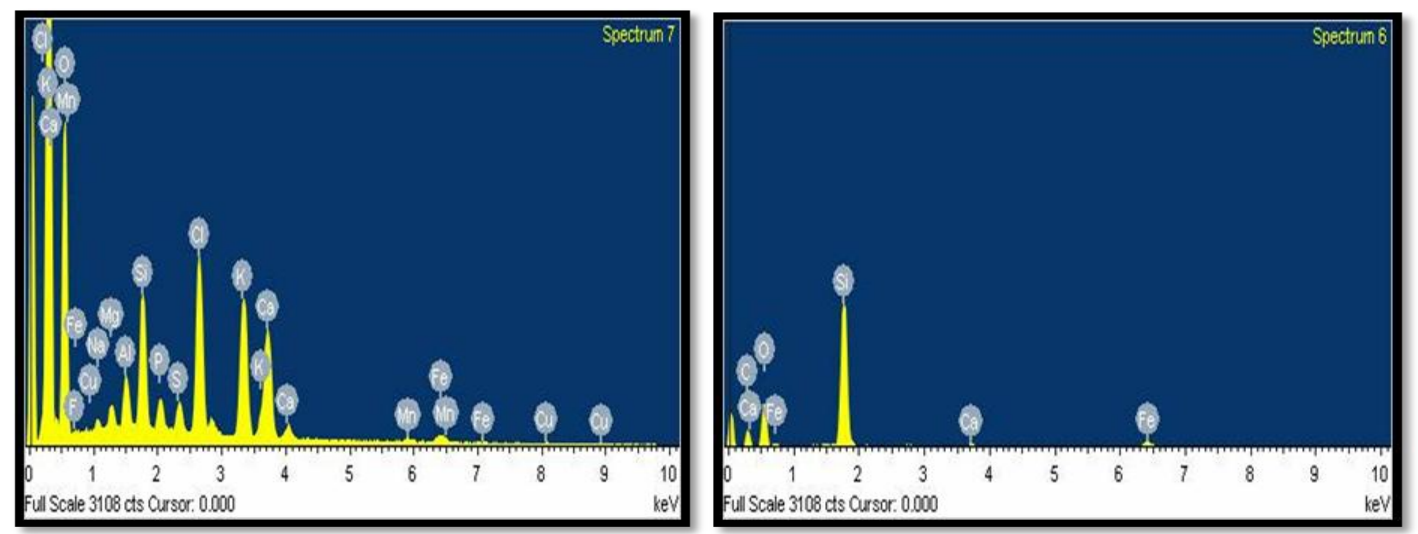

Figure 4: EDX Spectrum of the raw sample (Spectrum 7) and micro-particles (Spectrum 6).

\subsubsection{Thermo gravimetric Analysis (TGA)}

The TGA curve of raw sample and micro-particles are shown in Fig 5. The moisture loss due to adsorbed water was from $75-150{ }^{\circ} \mathrm{C}$ in processed sample and in raw sample was from $50-150{ }^{\circ} \mathrm{C}$. Similar studies by Sundari and Ramesh, (2012) [22] also shows similar results. The moisture loss was $23.50 \%$ by mass of the biomass in micro-particles and $6.97 \%$ in raw sample. In raw sample hemicelluloses, lignin and pectin began to degrade at around $220^{\circ} \mathrm{C}$ and they constituted $37.89 \%$ of the total mass. In the micro-particle sample, hemicelluloses and pectin decomposed around $250-350^{\circ} \mathrm{C}$ and cellulose began to decompose around $280-370^{\circ} \mathrm{C}$ all constituting $28.42 \%$ by mass. Similar results were obtained by Deepa et al., (2011) and also by Khawas and Deka, (2016)[19] [25].

Carbonaceous material in the raw sample began to decompose around $400-860^{\circ} \mathrm{C}$ and the degradation temperature of the crude fibre was around $220^{\circ} \mathrm{C}$, whereas in the micro-particle sample, it began to decompose from about 400 to $560^{\circ} \mathrm{C}$ and the decomposition temperature of the particles was around $250^{\circ} \mathrm{C}$.

The residue of treated and untreated $H$. ranunculoides particles remained was different, the amount of residue in the treated sample was $15.22 \%$ and in the untreated sample was $33.545 \%$. The difference was probably due to the removal of lignin, hemicelluloses, and silicon dioxide. The fact that the decomposition temperature increased means that the compound is stronger structurally and the decomposition patterns confirmed the existence of cellulose, pectin, lignin, and carbonaceous compounds in the material.

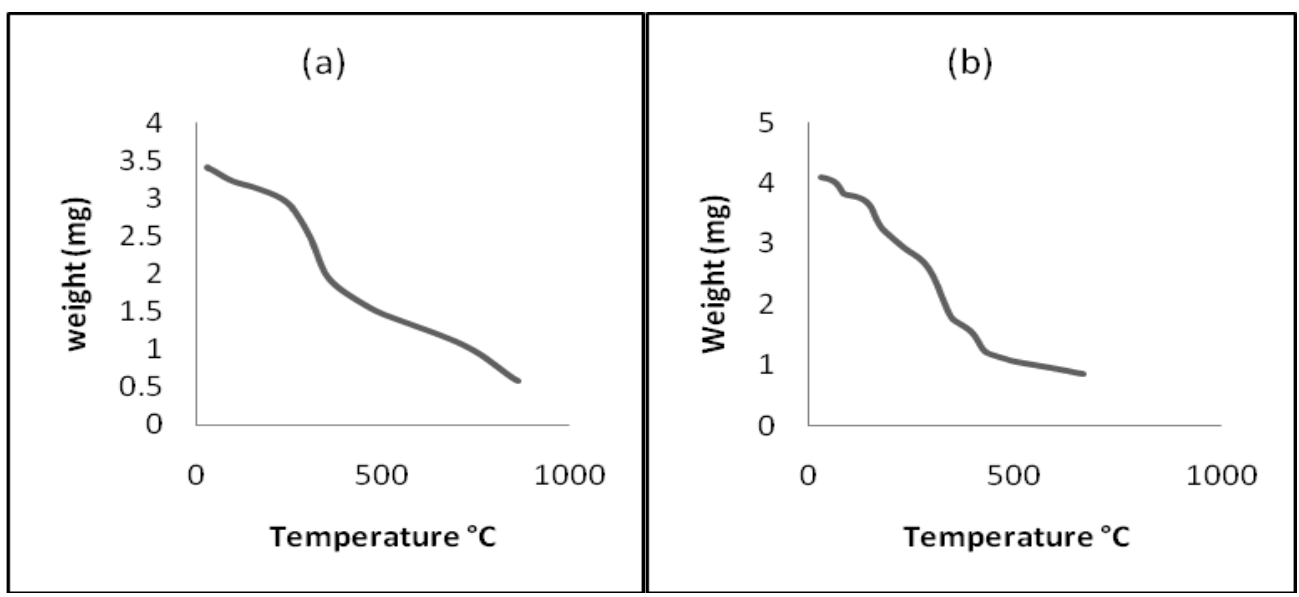

Figure 5. TGA thermogram for (a) raw plant and (b) micro-particles sample

\subsection{Acceptance criteria and data Analysis}

The linearity, applicability range, Limit of Detection (LOD), limit of quantification (LOQ), accuracy, precision, repeatability and reproducibility were used to validate the method. LOD and LOQ were determined from ten replicates of standard solution with concentration close to the blank. The parameters were calculated using the equation (3) and (4).

$$
\begin{aligned}
& \text { LOQ }=\frac{10 S d}{b} \\
& \text { LOD }=3.3 \frac{s d}{b}
\end{aligned}
$$

Where $\mathrm{SD}=$ standard deviation, $\mathrm{b}=$ slope of curve. 
Applicability range was established by preparing a wide range of standards of heavy $M^{2+}$ ions in the range $0-25 \mathrm{mg} / \mathrm{L}$. the absorbance was plotted versus concentration and in order to establish the range of work only standards that provide linear correlation were selected.

Reproducibility (R) was determined by evaluating 10 replicates of a standard solution carried out on three different days. Repeatability ( $\mathrm{r}$ ) was evaluated from 10 replicates of a standard solution in the same day. Reproducibility and repeatability were expressed as relative standard deviation $R S D_{R}$ and $R S D_{r}$ respectively. The Horwitz equation was used to calculate the theoretical $R S D_{R}$ and $R S D_{r}$ respectively. The Horwitz equation is : $\sigma_{H}=0.02(\mathrm{c})^{0.8495}$ where $\sigma_{H}$ is predicted reproducibility standard deviation and c, is the concentration [29].

Table 1. Acceptance criteria

\begin{tabular}{|l|l|}
\hline PARAMETER & REQUIREMENT \\
\hline Linearity & $\boldsymbol{R}^{2}>0.900$ \\
\hline Repeatability & $\boldsymbol{R S} \boldsymbol{D}_{\boldsymbol{r}}<0.5 \boldsymbol{R S D}_{\boldsymbol{r}}$ theoretical \\
\hline Reproducibility & $\boldsymbol{R S} \boldsymbol{D}_{\boldsymbol{R}}<0.5 \boldsymbol{R S D _ { \boldsymbol { R } }}$ theoretical \\
\hline
\end{tabular}

The calibration curve was linear between $0-20 \mathrm{mg} / \mathrm{L}$, thus all samples were diluted to fall within this range in order to achieve accurate results. The limit of quantification (LOQ) was found to be $5.909 \mathrm{mg} / \mathrm{L}$ and was considered appropriate since most of the samples in the experiments had concentrations above $5 \mathrm{mg} / \mathrm{L}$ for most of the analysis. The relative standard deviations for repeatability and reproducibility were less than $0.5 \mathrm{RSD}_{\mathrm{r}}$ and $0.5 \mathrm{RSD}_{\mathrm{R}}$ respectively hence repeatability and reproducibility of the analysis were acceptable.

\subsubsection{Effect of $\mathrm{pH}$}

The effect of $\mathrm{pH}$ (Fig 8) on cadmium adsorption was determined from $\mathrm{pH} 2.0$ to 8.0 and all the other variables such as initial concentration, adsorbent dosage and temperature remained constant. When the initial $\mathrm{pH}$ was increased from 2.0 to $\mathrm{pH} 5.0$ an increase in cadmium uptake was observed probably because the adsorbent is protonated at low $\mathrm{pH}$, however higher $\mathrm{pH}$ favours ion exchange because the adsorbent will be deprotonated. The optimum $\mathrm{pH}$ for $\mathrm{Cd}$ (II) adsorption was at $\mathrm{pH} 5.0$ and was used during the experiments and similar results were found by Ammari et al., (2015)[9], Stephen et al., (2011)[18]. The percentage Cd (II) uptake decreased at $\mathrm{pH}$ above 5.0 and similar results were found by $\mathrm{Li}$ et al ., 2012) and they concludes that the concentration of cadmium species decreases with increase in $\mathrm{pH}$ whereas $\mathrm{Cd}$ (II) precipitates as hydroxides species such as $\left[\mathrm{Cd}(\mathrm{OH})_{4}\right]^{2-},\left[\mathrm{Cd}(\mathrm{OH})_{3}\right]^{-},\left[\mathrm{Cd}_{2}(\mathrm{OH})_{3}\right]^{+},\left[\mathrm{Cd}(\mathrm{OH})_{2}\right]$ and $[\mathrm{Cd}(\mathrm{OH})]^{+}$at higher pH resulting in their concentrations being higher in solution; however, the concentration of hydroxide decreases at lower $\mathrm{pH}$. The precipitates impede adsorption of Cd (II) by ion exchange since they are not charged.

\subsubsection{Effect of adsorbent dosage}

The effect of adsorbent dosage was investigated by contacting 1.0 to $5.0 \mathrm{~g} / \mathrm{L}$ of microparticles with $20 \mathrm{mg} / \mathrm{L} \mathrm{Cd}$ (II) at constant $\mathrm{pH}$, initial Cd (II) concentration, and temperature. The amount of Cd (II) removed increased with increase in dosage as shown in Fig 6, however, dosages above $2.0 \mathrm{~g} / \mathrm{L}$ produced small changes in the percentage Cd (II) uptake. The results agrees with similar studies by Anirudhan and Shainy, (2015)[31] and this can be attributed to clumping of adsorbent at higher dosage.

\subsubsection{Effect of contact time}

The quality of the adsorbent is gauged by a high rate of removal of toxic substances from wastewater [18]. The effect of contact time was determined by contacting the micro-particles with cadmium solution for five hours. It was found that uptake of Cd (II) increased gradually during the initial stages as shown in Fig 7 probably due to the presence of abundant free active sites on the adsorbent. Equilibrium was reached after 240 minutes at $\mathrm{pH} 5.0$.

\subsubsection{Effect of Initial Concentration}

The effect of initial cadmium concentration was investigated at $0-80 \mathrm{mg} / \mathrm{L} \mathrm{Cd}, \mathrm{pH} 5.0$, adsorbent dosage $2 \mathrm{~g} / \mathrm{L}$. the results in Fig 9 shows that the adsorption capacity increased with increase in initial concentration and was maximal at $60 \mathrm{mg} / \mathrm{L}$ initial Cd (II) concentration. The results can be attributed to a large number of free active site at the beginning and in the end saturation of fixed number of active sites for the same amount of adsorbent[15]. 


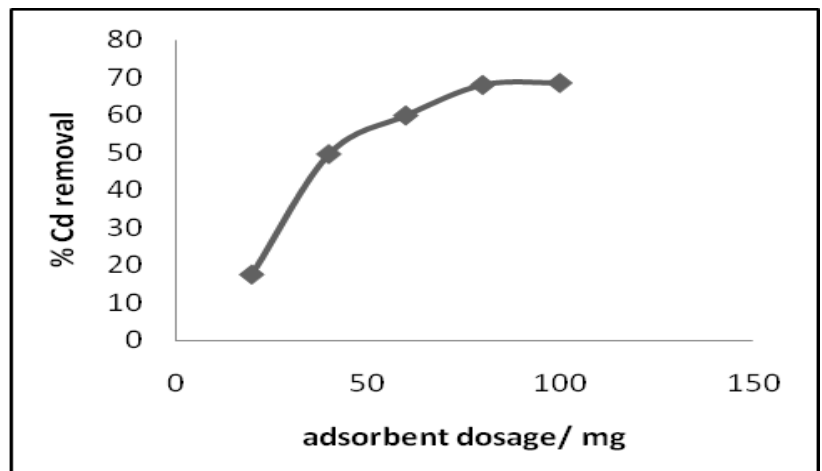

Figure 6. Effect of adsorbent dosage at $\mathrm{pH} 5.0$ and $20 \mathrm{mg} / \mathrm{L}$ initial $\mathrm{Cd}$ (II) concentration

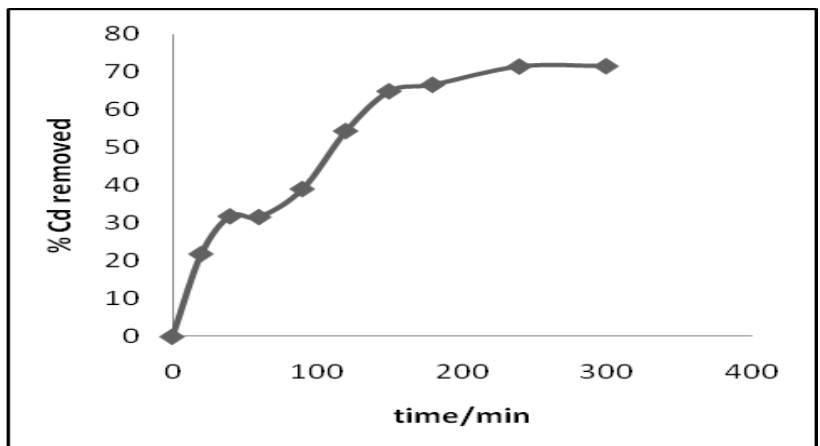

Figure 7. Effect of contact time at $\mathrm{pH} 5.0,50 \mathrm{mg} / \mathrm{L}$ initial $\mathrm{Cd}$ concentration, and $0.04 \mathrm{~g}$ adsorbent dosage.

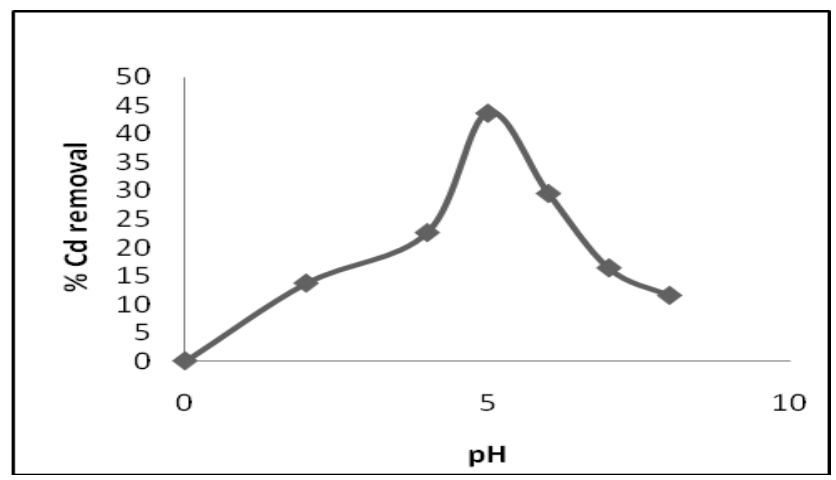

Figure 8. Effect of $\mathrm{pH}$ on cadmium adsorption at $50 \mathrm{mg} / \mathrm{L}$ initial $\mathrm{Cd}$ and $0.04 \mathrm{~g}$ adsorbent dosage.

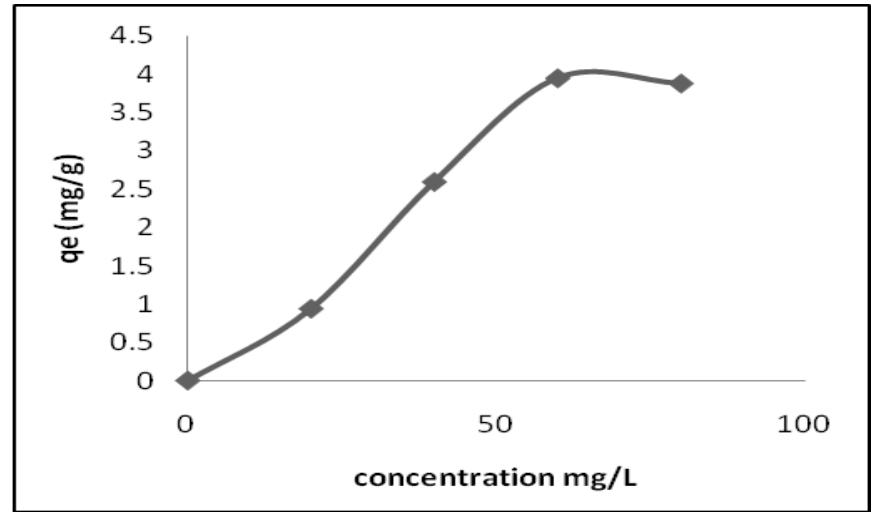

Figure 9. Effect of initial cadmium concentration at $\mathrm{pH} 5.0$, adsorbent dosage $0.04 \mathrm{~g}$.

\subsubsection{Adsorption Equilibrium Studies}

The isotherm data was analysed using Temkin, Langmuir, Freundlich, and Dubinin-Radushkevich isotherm models (Fig 10) in order to describe the uptake of Cd (II) by the micro-particles. The Langmuir isotherm model describes how the adsorbate assumes a monolayer onto the surface of the adsorbent. In order to 
Synthesis of micro-particles using Hydrocotyle Ranunculoides (Floating Water Pennywort) and ..

determine the feasibility of the adsorption process, the essential characteristic of the Langmuir isotherm equation is expressed as the dimensionless constant or separation factor $R_{L}=\frac{1}{1+b c_{0}}$. If it is between $0-1$ adsorption is favourable. The Freundlich isotherm model is based on the assumption that monolayer sorption occurs with heterogeneous energetic distribution of active sites, accompanied by interaction between sorbed species[32].Tempkin Isotherm model assumes that adsorption is characterised by uniform distribution of binding energies up to a certain maximum binding energies and adsorbent adsorbate interactions results in the heat of adsorption of all molecules in the layer decreasing linearly with coverage[33]. Dubinin-Radushkevich Isotherm model is used to determine if adsorption is physical or chemical [34]. The constants for the four models are shown in Table 2. The adsorption data was best fitted by the Dubinin-Radushkevich isotherm model $\left(\mathrm{R}^{2}=0.981\right)$ which determines if adsorption is physical or chemical. The value of $E$ was $5.773 \mathrm{~kJ} / \mathrm{mol}$ and it indicates that the adsorption process is mainly of a physical nature. If $E$ is between 8 and $16 \mathrm{~kJ} / \mathrm{mol}$ the mechanism for adsorption is chemical ion exchange and if $\mathrm{E}<8 \mathrm{~kJ} / \mathrm{mol}$ the mechanism is of a physical nature [15]. The maximum adsorption capacity of $H$. ranunculoides micro-particles was determined using the Langmuir adsorption isotherm was $20.40 \mathrm{mg} / \mathrm{g}$. The separation factor $\left(\mathrm{R}_{\mathrm{L}}\right)$ was between 0.9099 and 0.7163 indicating that adsorption is favourable since $0<\mathrm{R}_{\mathrm{L}}<1$.

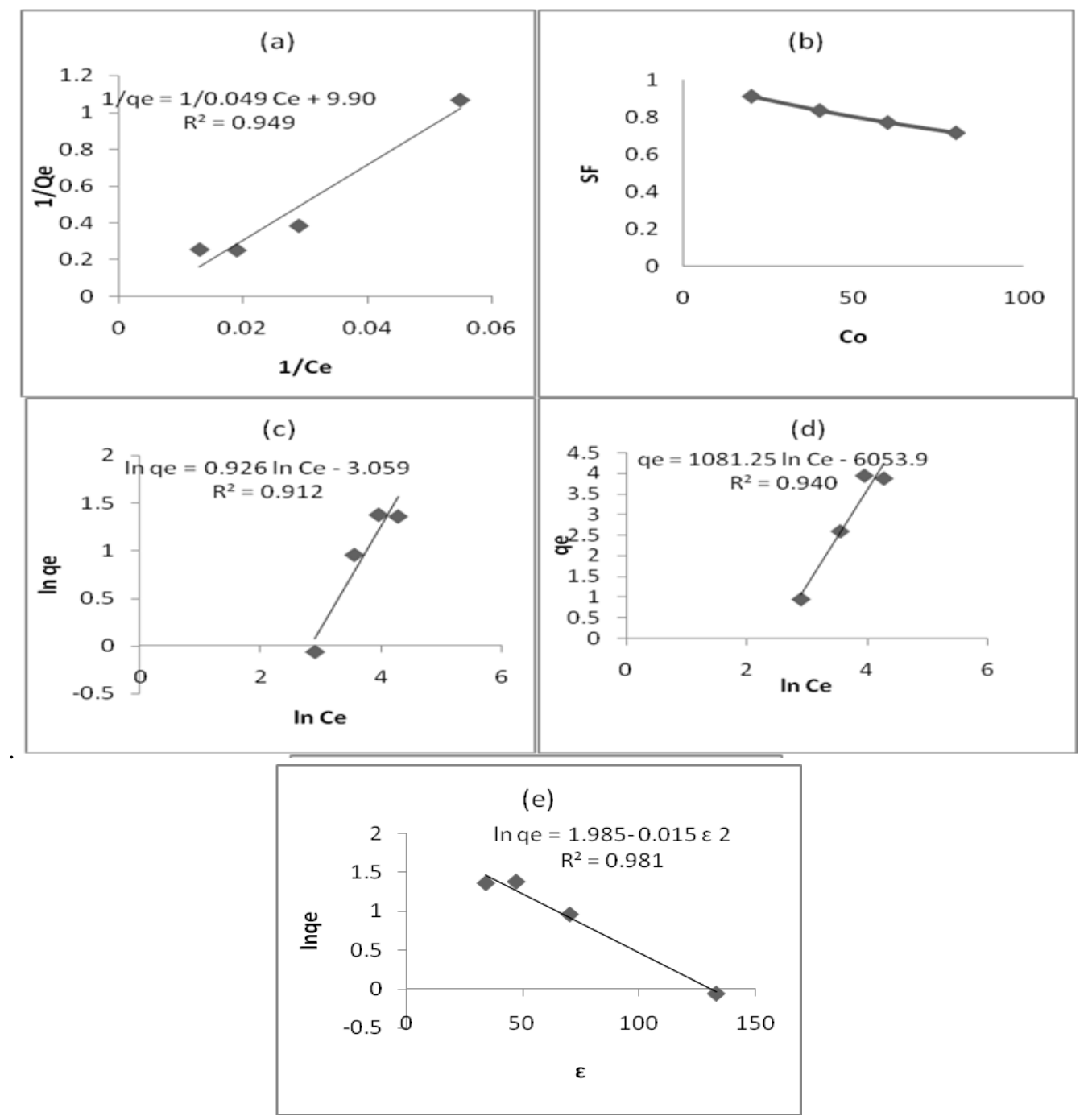

Figure 10. The linear isotherms of $H$. ranunculoides micro-particles by applying (a) Langmuir (b) separation factor (c) Freundlich (d) Temkin (e) Dubinin-Radushkevich isotherm models.

Table 2. Langmuir, Freundlich, D-R and Temkin isotherm parameters

\begin{tabular}{|c|c|c|c|c|c|c|c|c|c|c|c|c|c|}
\hline \multicolumn{4}{|c|}{ Langmuir } & \multicolumn{3}{|c|}{ Freundlich } & \multicolumn{4}{|l|}{ D-R } & \multicolumn{3}{|c|}{ Temkin } \\
\hline $\begin{array}{l}\mathbf{Q} \\
(\mathrm{mg} / \mathrm{g})\end{array}$ & $\begin{array}{l}\mathrm{B} \\
(\mathrm{L} / \mathrm{mg})\end{array}$ & $\mathrm{R}$ & $R_{\mathrm{L}}$ & $\begin{array}{l}K_{F} \\
(\mathrm{mg} / \mathrm{g})\end{array}$ & $\mathrm{n}$ & $\mathrm{R}$ & $X_{\mathrm{m}}(\mathrm{mg} / \mathrm{g})$ & $\begin{array}{l}K_{D I} \\
\left(m o l f^{2}\right)^{2}\end{array}$ & $\begin{array}{l}\mathrm{E} \\
(\mathrm{KJ} / \mathrm{mol})\end{array}$ & $\mathrm{R}$ & $\begin{array}{l}K_{T} \\
(\mathrm{~L} / \mathrm{g})\end{array}$ & $\begin{array}{l}\mathrm{B} \\
\mathrm{J} / \mathrm{mol}\end{array}$ & $\mathrm{R}$ \\
\hline 20.4 & 9.90 & 0.95 & $\begin{array}{l}0.91 \text { to } \\
0.72\end{array}$ & 0.047 & 0,9 & 0.91 & 7.28 & -0.015 & 5.77 & 0.98 & -5.86 & 1081.2 & 0.94 \\
\hline
\end{tabular}


Synthesis of micro-particles using Hydrocotyle Ranunculoides (Floating Water Pennywort) and ..

The comparison of the adsorption capacities of $H$. ranunculoides micro-particles with that of various adsorbents is shown in Table 3. The adsorbent used in the current study exhibited reasonable adsorption capacity for cadmium from aqueous solution when compared to other adsorbents in the table. Since H. Ranunculoides is a nuisance pollutant and is, widely available it can be used as an alternative material to remediate wastewaters polluted with $\mathrm{Cd}$ (II).

Table 3. Comparison of adsorbent available for removal of cadmium with present study

\begin{tabular}{|c|c|c|c|c|c|c|}
\hline Adsorbents & $\begin{array}{l}\text { Maximum } \\
\text { adsorption } \\
\text { capacity mg/g }\end{array}$ & $\begin{array}{l}\text { Adsorbent } \\
\text { Dosage } \\
\text { g/L }\end{array}$ & pH & $\begin{array}{l}\text { Equilibrium } \\
\text { Time } \\
\text { /minutes }\end{array}$ & Isotherm & Reference \\
\hline $\begin{array}{l}\text { 2-mercaptobenzamide modified itaconic acid } \\
\text { grafted magnetite nanocellulose composite }\end{array}$ & 262.27 & 2.0 & 6.0 & 90 & Sips & [31] \\
\hline $\begin{array}{l}\text { Cellulose based electrospun nanofibers } \\
\text { membrane }\end{array}$ & 34.70 & 2.5 & 6.0 & 600 & Langmuir & [35] \\
\hline Untreated coffee grounds & 15.65 & 90.0 & 7.0 & 120 & Langmuir & [15] \\
\hline Pinus halepensis sawdust & 5.36 & 10.0 & 9.0 & 30 & Freundlich & [13] \\
\hline Cyperus laevigatus & 7.49 & 5.0 & 5.5 & 120 & Freundlich & [9] \\
\hline Alhaji maurorum seed & 3.748 & 20 & 6.0 & 45 & Freundlich & [12] \\
\hline H. ranunculoides micro-particles & 20.40 & 2.0 & 5.0 & 240 & $\begin{array}{l}\text { Dubinin } \\
\text { Radushkevich }\end{array}$ & This study \\
\hline
\end{tabular}

\section{Conclusion}

Most of the metallic impurities were totally removed and some were reduced in concentration as shown by the EDX spectra. The decomposition temperature increased as shown by TGA in treated particles due to the removal of lignin, hemicellulose, and silicon dioxide. Fourier Transform infrared spectra indicated that most of lignin, pectin, and hemicellulose were removed as shown by disappearance as well as decrease in intensity of functional groups. The SEM images shows that the size of the micro-particles decreased after the steam explosion process and the TEM images shows that bunches of particles in the micro-particles were fragmented. The adsorption process was affected by changes in $\mathrm{pH}$, dosage, $\mathrm{Cd}$ (II) concentration, and contact time during the present study. Dosage, $\mathrm{pH}$ and contact time all affected the adsorption process and the optimum conditions were determined from maximum $\mathrm{Cd}$ adsorption. Adsorption of cadmium using H. ranunculoides was shown to be favourable from the separation factor studies. It is necessary to chemically modify the adsorbent in order to introduce more functional groups to improve its adsorption capacity. Regeneration studies as well as column studies must be carried out in order to scale up the process to industrial plants.

\section{References}

[1]. H.G. Gorchev, G. Ozolins, WHO guidelines for drinking-water quality., WHO Chronicle. 38 (2011) 104-108. doi:10.1016/S14620758(00)00006-6.

[2]. C. Mahamadi, R. Chapeyama, Determination of cadmium, lead, nickel, and zinc in Micropterus salmoides and Oreochromis niloticus by flame atomic absorption spectrometry after cloud point extraction, Toxicological \& Environmental Chemistry. (2013). doi:10.1080/02772248.2012.752490.

[3]. a H. Siwela, C.B. Nyathi, Y.S. Naik, A comparison of metal levels and antioxidant enzymes in freshwater snails, Lymnaea natalensis, exposed to sediment and water collected from Wright Dam and Lower Mguza Dam, Bulawayo, Zimbabwe., Ecotoxicology and Environmental Safety. 73 (2010) 1728-32. doi:10.1016/j.ecoenv.2010.08.001.

[4]. M.L. Meck, J. Atlhopheng, W.R.L. Masamba, S. Ringrose, Pollution implications of Save River water from weathering and dissolution of metal hosting minerals at Dorowa phosphate mine, Zimbabwe, Physics and Chemistry of the Earth, Parts A/B/C. 35 (2010) 679-685. doi:10.1016/j.pce.2010.08.003.

[5]. M. STOJANOVIC, Z. LOPIČIĆ1, J. MILOJKOVIĆ, Č. LAČNJEVAC, M. MIHAJLOVIĆ, M. PETROVIĆ, A. KOSTIĆ, Biomass waste material as potential adsorbent for sequestering pollutants, ZAŠTITA MATERIJALA. 53 (2012) 231-237.

[6]. M. Tsezos, E. Remoundaki, A. Hatzikioseyian, Biosorption-Principles and applications for metal immobilization from wastewater streams, in: Proceedings of EU-Asia ..., 2006: pp. 30-40.

[7]. R.H.S.F. Vieira, B. Volesky, Biosorption: a solution to pollution?, International Microbiology. 3 (2000) 17-24.

[8]. H.N. Bhatti, R. Hafiz, M.A. Hanif, Adsorptive removal of chromium ions from synthetic effluents by Mentha arvensis biomass : kinetic and equilibrium modeling, International Journal of Chemical and Environmental Engineering. 2 (2011) $261-265$.

[9]. T.G. Ammari, I. Al-Labadi, A. Tahboub, A. Ghrair, Assessment of unmodified wetland bio-waste: Shoots of Cyperus laevigatus, for cadmium adsorption from aqueous solutions, Process Safety and Environmental Protection. 95 (2015) 77-85. doi:10.1016/j.psep.2015.02.015.

[10]. A. Moubarik, N. Grimi, Valorization of olive stone and sugar cane bagasse by-products as biosorbents for the removal of cadmium from aqueous solution, Food Research International. 73 (2014) 169-175. doi:10.1016/j.foodres.2014.07.050.

[11]. P. Chand, A.K. Shil, M. Sharma, Y.B. Pakade, Improved adsorption of cadmium ions from aqueous solution using chemically modified apple pomace: Mechanism, kinetics, and thermodynamics, International Biodeterioration \& Biodegradation. 90 (2014) 8 16. doi:10.1016/j.ibiod.2013.10.028.

[12]. A. Ebrahimi, M. Ehteshami, B. Dahrazma, Isotherm and kinetic studies for the biosorption of cadmium from aqueous solution by

[13]. L. Semerjian, Equilibrium and kinetics of cadmium adsorption from aqueous solutions using untreated Pinus halepensis sawdust, Journal of Hazardous Materials. 173 (2010) 236-242. doi:10.1016/j.jhazmat.2009.08.074.

[14]. M.M.S. Saif, N.S. Kumar, M.N. V Prasad, Binding of cadmium to Strychnos potatorum seed proteins in aqueous solution: Adsorption kinetics and relevance to water purification, Colloids and Surfaces B: Biointerfaces. 94 (2012) 73-79. 
doi:10.1016/j.colsurfb.2012.01.039.

[15]. N. Azouaou, Z. Sadaoui, A. Djaafri, H. Mokaddem, Adsorption of cadmium from aqueous solution onto untreated coffee grounds: Equilibrium, kinetics and thermodynamics, Journal of Hazardous Materials. 184 (2010) 126-134. doi:10.1016/j.jhazmat.2010.08.014.

[16]. M. C, T. E, D. P, Extraction of phenolic compounds from Temnocalyx obovatus, African Journal of Biotechnology. 10 (2011) 11245-11248. doi:10.5897/AJB11.351.

[17]. C. Magadza, Management of Eutrophication in Lake Chivero; Success and failures : A Case Study ., in: Proceedings of Taal2007: The 12 Th World Lake Conference, 2008: pp. 790-798.

[18]. M. Stephen, N. Catherine, M. Brenda, K. Andrew, P. Leslie, G. Corrine, Oxolane-2,5-dione modified electrospun cellulose nanofibers for heavy metals adsorption, Journal of Hazardous Materials. 192 (2011) 922-927. doi:10.1016/j.jhazmat.2011.06.001.

[19]. B. Deepa, E. Abraham, B.M. Cherian, A. Bismarck, J.J. Blaker, L. a. Pothan, A.L. Leao, S.F. de Souza, M. Kottaisamy, Structure, morphology and thermal characteristics of banana nano fibers obtained by steam explosion, Bioresource Technology. 102 (2011) 1988-1997. doi:10.1016/j.biortech.2010.09.030.

[20]. Velayudham Navaneetha Krishnan, Atmakuru Ramesh, Synthesis and Characterization of Cellulose Nanofibers From Coconut Coir Fibers, IOSR Journal of Applied Chemistry (IOSR-JAC). 6 (2013) 18-23.

[21]. H. Tibolla, F. Maria, F. Cecilia, LWT - Food Science and Technology Cellulose nano fi bers produced from banana peel by chemical and enzymatic treatment, LWT - Food Science and Technology. 59 (2014) 1311-1318. doi:10.1016/j.lwt.2014.04.011.

[22]. M.T. Sundari, A. Ramesh, Isolation and characterization of cellulose nanofibers from the aquatic weed water hyacinth Eichhornia crassipes, Carbohydrate Polymers. 87 (2012) 1701-1705. doi:10.1016/j.carbpol.2011.09.076.

[23]. J.C. C.S., N. George, S.K. Narayanankutty, Isolation and Characterization of Cellulose Nanofibrils From Arecanut Husk Fibre, Carbohydrate Polymers. 142 (2016) 158-166. doi:10.1016/j.carbpol.2016.01.015.

[24]. P. Khawas, S.C. Deka, Isolation and characterization of cellulose nanofibers from culinary banana peel using high-intensity ultrasonication combined with chemical treatment, Carbohydrate Polymers. $137 \quad$ (2015) 608-616. doi:10.1016/j.carbpol.2015.11.020.

[25]. P. Khawas, S.C. Deka, Isolation and characterization of cellulose nanofibers from culinary banana peel using high-intensity ultrasonication combined with chemical treatment, Carbohydrate Polymers. 137 (2016) 608-616. doi:10.1016/j.carbpol.2015.11.020.

[26]. S. Xiao, R. Gao, Y. Lu, J. Li, Q. Sun, Fabrication and characterization of nanofibrillated cellulose and its aerogels from natural pine needles., Carbohydrate Polymers. 119 (2015) 202-9. doi:10.1016/j.carbpol.2014.11.041

[27]. E. Kalita, B.K. Nath, P. Deb, F. Agan, M.R. Islam, K. Saikia, High quality fluorescent cellulose nanofibers from endemic rice husk: isolation and characterization., Carbohydrate Polymers. 122 (2015) 308-13. doi:10.1016/j.carbpol.2014.12.075.

[28]. M. Thiripura Sundari, A. Ramesh, Isolation and characterization of cellulose nanofibers from the aquatic weed water hyacinth Eichhornia crassipes, Carbohydrate Polymers. 87 (2012) 1701-1705. doi:10.1016/j.carbpol.2011.09.076.

[29]. M. Thompson, The amazing Horwitz function, Royal Society of Chemistry. (2004).

[30]. Q. Li, L. Chai, W. Qin, Cadmium(II) adsorption on esterified spent grain: Equilibrium modeling and possible mechanisms, Chemical Engineering Journal. 197 (2012) 173-180. doi:10.1016/j.cej.2012.04.102.

[31]. T.S. Anirudhan, F. Shainy, Adsorption behaviour of 2-mercaptobenzamide modified itaconic acid-grafted-magnetite nanocellulose composite for cadmium(II) from aqueous solutions, Journal of Industrial and Engineering Chemistry. 32 (2015) 157-166. doi:10.1016/j.jiec.2015.08.011.

[32]. J. Plaza, M. Viera, E. Donati, E. Guibal, Biosorption of mercury by Macrocystis pyrifera and Undaria pinnatifida: Influence of zinc, cadmium and nickel, Journal of Environmental Sciences. 23 (2011) 1778-1786. doi:10.1016/S1001-0742(10)60650-X.

[33]. D. Vu, Z. Li, H. Zhang, W. Wang, Z. Wang, X. Xu, B. Dong, C. Wang, Adsorption of $\mathrm{Cu}$ (II) from aqueous solution by anatase mesoporous TiO2 nanofibers prepared via electrospinning., Journal of Colloid and Interface Science. 367 (2012) 429-35. doi:10.1016/j.jcis.2011.09.088.

[34]. R. Karthik, S. Meenakshi, Removal of $\mathrm{Pb}$ ( II ) and Cd ( II ) ions from aqueous solution using polyaniline grafted chitosan, CHEMICAL ENGINEERING JOURNAL. 263 (2015) 168-177. doi:10.1016/j.cej.2014.11.015.

[35]. T. Xiang, Z. Zhang, H. Liu, Z. Yin, L. Li, X. Liu, Characterization of cellulose-based electrospun nanofiber membrane and its adsorptive behaviours using $\mathrm{Cu}(\mathrm{II}), \mathrm{Cd}(\mathrm{II}), \mathrm{Pb}$ (II) as models, Science China Chemistry. 56 (2013) 567-575. doi:10.1007/s11426012-4783-7. 